\title{
Universiteit
}

Leiden

The Netherlands

\section{Religiosity with/out religion: Hans J. Morgenthau, disenchantment and international politics}

Valk, J.H.; Paipais, V.

\section{Citation}

Valk, J. H. (2020). Religiosity with/out religion: Hans J.

Morgenthau, disenchantment and international politics. In V.

Paipais (Ed.), Theology and World Politics: Metaphysics,

Genealogies, Political Theologies (pp. 315-343). Cham,

Switzerland: Palgrave Macmillan.

doi:10.1007/978-3-030-37602-4_13

Version: $\quad$ Publisher's Version

License: $\quad$ Licensed under Article 25fa Copyright Act/Law (Amendment Taverne)

Downloaded from: $\quad$ https://hdl.handle.net/1887/137992

Note: To cite this publication please use the final published version (if applicable). 


\title{
Religiosity with/out Religion: Hans J. Morgenthau, Disenchantment and International Politics
}

\author{
John-Harmen Valk
}

\section{INTRODUCTION}

In a 1955 review of the second installment of volumes comprising the British historian Arnold Toynbee's massive 12-volume work A Study of History, Hans J. Morgenthau (1962i, 60) formulates a distinction between what he terms religion, on the one hand, and religiosity, on the other. ${ }^{1}$ This review is one of the select few places where he explicitly articulates this distinction, his $(1983,15)$ posthumously published writings on Abraham Lincoln being another. ${ }^{2}$ Yet, the limited instances of overt exploration of these two notions belie the central importance of this distinction to Morgenthau's overall outlook regarding the character of international politics in the late-modern era. That this distinction is fundamental to Morgenthau's entire framework is evident, for example, in the claim which opens Morgenthau's $(1983,6)$ exploration of the qualities that make Abraham Lincoln the man who, above all others, serves for Morgenthau in his later years as the pre-eminent statesman, namely, the claim that the

\footnotetext{
J.-H. Valk $(\bowtie)$

Leiden University, Leiden, Netherlands

e-mail: j.h.valk@hum.leidenuniv.nl
}

(C) The Author(s) 2020

V. Paipais (ed.), Theology and World Politics, International Political

Theory, https://doi.org/10.1007/978-3-030-37602-4_13 
issue of religion and religiosity is the "issue that precedes all others both in time and importance". Unpacking the contours of Morgenthau's distinction between religion and religiosity therefore holds value in so much as attention to this aspect of Morgenthau's thought can both further elucidate Morgenthau's overall understanding of the condition of late modernity at the level of international politics and reveal the limits of his understanding. ${ }^{3}$ Attention to Morgenthau's distinction between religion and religiosity reveals that the distinction rests on a problematic separation between lived experience and symbolic expression that runs contrary to aspects of his own thought and that serves to preclude resources that might sustain the sort of limited transformation at the level of international politics that Morgenthau desires. ${ }^{4}$ The question of Morgenthau's characterization of religion, religiosity and the relationship between them links up with much broader questions regarding the place of religious symbolic expression in late modernity generally-questions concerning disenchantment and secularization (Löwith 1949; Blumenberg 1983; Gauchet 1997; Taylor 2007)—and in late-modern politics specificallyquestions concerning the permanence of the so-called theologico-political (Lefort 1988; Schmitt 2005). An investigation of Morgenthau's characterization would suggest that those broader questions are much more complicated than would be implied by flippant dismissals that relegate religious symbolic expressions to a previous era rather than exploring how they are taken up, transformed and refashioned.

\section{Morgenthau on Religion and Religiosity}

For Morgenthau, religion is an organized affair pertaining to membership in established communities. It can entail assent to particular statements, the profession of faith in particular dogmas. It can also involve regular performance of practices. In short, religion is institutional, propositional or ritualistic (1962i, 60-61, 1983, 6). Religiosity, for Morgenthau, is not the stuff of institutions, propositions or rituals but rather an attitude that stems from a basic human experience which transcends particularistic affiliations. The experience is one of suffering-Morgenthau describes it also as disquiet, fear and existential dread $(1972,26,29-30,35,52-53,55$, $58)^{5}$ - arising from a recognition of ignorance and impotence in the face of the unforeseen and unintelligible (1947, 176, 1972, 25, 55, 66-67), and which in religiosity is "transformed into intellectual and moral awareness by mind and conscience" (1962i, 62). This awareness "recognizes the 
insufficiency of man as a finite being and seeks to orient itself through some transcendent guidance, so that man can come to terms with himself, his fellowmen, and the universe" $(1983,6)$. Further characterizing the nature of the experience which in religiosity is transformed into conscious awareness, Morgenthau states that religiosity is thus a "human experience of mystery, tragedy, and guilt" (1962i, 60). Such an attitude of religiosity, suggests Morgenthau, lies outwith religion. It is a broader category that envelops religion, a universal human attitude in the sense that religious believers, atheists and agnostics alike can hold it $(1983,6)$.

The potentially universal purchase of the attitude of religiosity notwithstanding, Morgenthau asserts that a defining feature of modernityindeed a feature unique to this era of human history $(1947,11)$-is its lack of religiosity. Modernity exhibits an attitude of "irreligious selfglorification, which in a sense is [its] self-mutilation" (1962i, 60). Regarding this distinctive attitude of modernity, Morgenthau states: "Modern man, as he sees himself, has become a self-sufficient entity who knows what he sees and can do what he wills. He has lost the awareness of his dependence upon a will and a power which are beyond his understanding and control" (1962i, 60). Here, evident in brief is an articulation of what Max Weber terms the modern disenchantment of the world. The modern disenchantment of the world, as Weber characterizes it, entails the loss of belief in mysterious forces at play in the world that inscribe limits to human power and capability. It instead gives rise to "the knowledge or belief that if one but wished one could learn it at any time" (Weber 1946, 139; emphasis in original). What at heart characterizes modern disenchantment is a shift in belief, a shift from the belief in mysterious forces to the belief that all problems are in principle solvable by the application of human reason. One sees evident echoes of this Weberian characterization of disenchantment in Morgenthau's claim that

The Age of Science has completely lost this awareness of unresolvable discord, contradictions, and conflicts which are inherent in the nature of things and which human reason is powerless to solve. For this age the problems which confront the human mind, and the conflicts which disturb and destroy human existence, belong of necessity to one of two categories: those which are already being solved by reason and those which are going to be solved in a not too distant future. $(1947,175)$ 
Important to note about this articulation of the modern disenchantment of the world is that modern disenchantment does not merely represent a stripping away of belief. The process of disenchantment is thus better understood as a dual vector of disenchantment and re-enchantment. The disenchantment of the belief in mysterious forces gives way to a reenchantment in the form of a "quasi-religious faith" that all problems are in principle solvable $(1972,5)$.

Noting the character of modern disenchantment as a shift in belief, and not as the stripping away of belief, is important in that it situates the irreligiosity of the modern era as a response, in stark distinction to that of religiosity, to the more fundamental, universally shared human experience from which modern irreligiosity arises. In response to the fundamental human experience of suffering in the face of the unforeseen and the unintelligible, this attitude of "irreligious self-glorification" seeks to "push [the mysteries and unfathomable forces of the universe] back and ultimately dissolve them" $(1972,25)$. It is an attitude that responds to the unpredictability and incomprehensibility of human action through "an understanding that portends mastery" $(1972,30)$, a shift from the recognition of an unavoidable mystery to a stance of mastery and control.

The attitude of modern irreligiosity that seeks mastery in response to the experience of the unforeseen and unintelligible is, according to Morgenthau, one trajectory akin to a number of similar irreligious trajectories that flow from the experience of suffering in the face of the unforeseen and unintelligible. In the face of the unforeseen and unintelligible, humanity tries in various ways to transcend the limits of its capacity. Morgenthau points to four figures each representative of typical trajectories of the attempt to possess all and thus of a form of self-transcending that seeks to push back or hide limits rather than to reconcile with them: the religious mystic who seeks union with the universe; Don Juan who pursues an insatiable love; Faust's quest for knowledge; and the lust for power of the world conqueror who seeks political domination (1947, 166, 1972, 9, 25). Regarding the latter, Morgenthau refers to Cecil Rhodes' desire for universal domination, quoting his lament: “These stars that you see overhead at night, these vast worlds which we can never reach. I would annex the planets if I could. I often think of that. It makes me sad to see them so clear and so far away" $(1947,166)$. Hence, mystical union, love, knowledge and the lust for power serve as trajectories whereby is manifest the human desire to transcend the experience of suffering in the face of the unforeseen and unintelligible, a desire that can take the form of religiosity- 
that is, the recognition of limits and the appeal to some transcendent guidance so as to reconcile with those limits - and the form of irreligiosity - the attempt to master the natural world and human nature. Elsewhere, Morgenthau speaks of yet more such trajectories: the pursuit of freedom, the quest for immortality and the desire for justice $(1970,62)$.

Morgenthau also speaks of religion as a particular trajectory in response to the experience of suffering in the face of the unforeseen and unintelligible. In the form of religiosity, it is a trajectory that seeks to make sense of the unforeseen and unintelligible through appeal to symbols, signs, images and parables $(1972,63,69) .^{6}$ Through such poetic forms, religion seeks to manifest the meaning and significance of the unknown, not at the level of theoretical or empirical knowledge but at the level of practical knowledge. Religion, then, like art, philosophy or science, serves as a mode of responding to the experience of limits to human capacity $(1972,69)$.

As one mode of response to the experience of suffering in the face of that which transcends human capacities, Morgenthau understands religion to be an outgrowth of the more fundamental religiosity of which he speaks. He refers to religiosity as the substance coursing through religion (1962i, 62). Elsewhere, he refers to religiosity as that "of which the historic religions, religious organizations, and religious observances are but particular manifestations" $(1983,6)$. Yet further, he speaks of religiosity as being "made rational in dogma and visible in organization" $(1983,9)$. The upshot is that religiosity can exist even in an age when society writ large no longer finds itself persuaded by the manner in which religious institutions, doctrines, rituals and symbols open up the meaning and significance of the unintelligible $(1972,65)$. There can, in short, be religiosity without religion.

But whether such a distinction between religion, conceived as symbolic expression, and religiosity, understood as a more fundamental awareness arising from a purportedly underlying common human experience, holds up in Morgenthau's own thinking is open to question. For, a closer examination of his articulation of the character of this experience would suggest that religious symbolic expression is intertwined with-indeed plays a central role in constituting - his very sense of religiosity and of the meaning of the experience Morgenthau assumes to be commonly shared. This central role becomes apparent with a further examination of the character of this experience as Morgenthau articulates it as well as his articulation of 
one particular trajectory — that of the desire for justice—by which humanity responds to this experience.

Morgenthau equates this experience to Aristotle's mega thaumazein, the shock of wonderment. To be in a state of wonderment, says Morgenthau, is to experience a desire that transcends ability, a longing to overcome limits to knowledge and power. This state of desire emerges in the face of the unforeseen and unintelligible, which reveal the failure of human reason and power to translate experience into knowledge and control $(1972,24-25)$. But, as noted previously, Morgenthau speaks of this experience of wonderment as more than a mere state of longing; he speaks of it more specifically as suffering. To become aware of the insufficiency of humanity with respect to the world, says Morgenthau, is to suffer. To recognize the inability to achieve itself as possibility is suffering. And this suffering initiates a vicious circle, as Morgenthau states: "Because man is conscious of himself he must suffer, and because he suffers he longs for more consciousness, and the more consciousness he has the more he must suffer.... the ultimate knowledge is beyond human possibility" (1972, 67). There exists an inevitability to suffering (1972, 55, 66-68). Elsewhere, Morgenthau depicts the shock of wonderment further as tragic (1947, 176). Humanity, he asserts, is suspended between heaven and earth, between animal and god. Unlike the animal that does not endeavor to be more than it is by nature and unlike a god who is already perfect and thus by definition cannot strive to be more than it is by nature, humanity seeks to be more than it is. Humanity is thus "an ambitious beast and a frustrated god. For he alone is endowed with the faculty of rational imagination that outpaces his ability to achieve" $(1970,61)$. Morgenthau adds: "Suspended between his spiritual destiny which he cannot fulfil and his animal nature in which he cannot remain, he is forever condemned to experience the contrast between the longings of his mind and his actual condition as his personal, eminently human tragedy" (1947, 188; see also $1972,9)$. Yet further, Morgenthau speaks of the shock as guilt (1962i, 60).

To characterize the shock of wonderment as suffering, tragedy and guilt is a particular characterization. Indeed, that one might read the experience of the unforeseen and unintelligible in a very different manner is evident in the challenge that the British philosopher Michael Oakeshott launches in his review of Morgenthau's Scientific Man vs. Power Politics, a point to which Nicholas Rengger (2007) gives much emphasis in his own rejoinder to Morgenthau's thought. Oakeshott (1993, 108) asserts that "the situation [Morgenthau] describes-the imperfectability of 
man-is not tragic, nor even a predicament, unless and until it is contrasted with a human nature susceptible of a perfection which is in fact foreign to its character, and rationalism rears its ugly head once more in any argument which assumes or asserts this contrast". Regardless of the merits of this Oakeshottian perspective, what it reveals is that Morgenthau's characterization of the experience of insufficiency in the face of the unforeseen and unintelligible specifically as suffering, tragedy and even guilt arises from a particular understanding of the human experience. It is an understanding that arises from Morgenthau's attempt to wrestle with the condition of late modernity framed not only by two pressing, concrete crises that modernity has brought about-nuclear weapons and environmental destruction $(1972,3)$ - but also by Nietzsche's critique of modern reason and religion mounted already much before.

On Morgenthau's view, Nietzsche's critique has had a devastating impact in that it has "left the received systems of thought empty of content and, in any event, without conviction. They live on as ritualistic incantations and ideological justifications and rationalizations, proclaiming their truth loudly but without rational vitality" (1958, 3, 1962b, 3). That Nietzsche hovers behind Morgenthau's discussions of international politics is a point that has now been emphasized by a host of scholars (Frei 2001; Petersen 1999; Rengger 2000, 9, 204; Paipais 2013, 2014, 2016). But the manner in which Nietzsche is present in Morgenthau's thinking is an issue that requires further consideration. For, as William Scheuerman $(2009,209 \mathrm{nl} l)$ recognizes, while Morgenthau sees truth in Nietzsche's critique of modernity, he by no means adopts it wholesale. Indeed, the very manner in which he pushes back against Nietzsche is enlightening for the question concerning the merit of Morgenthau's distinction between religion and religiosity. While recognizing that Nietzsche's critique of modern reason and religion has had the effect of rendering philosophy, religion and politics hollow in the late-modern era, Morgenthau rejects the notion that this need be the case. ${ }^{7}$ Hence, he asserts that the task is to address "the attitude peculiar to our age which denies the value of tradition" precisely by assuming "not only the continuing value of the tradition of political thought for the contemporary world but also the need for the restoration of its timeless elements" (1958, 3, 1962b, 3). Morgenthau notes that the unsettling critique launched by Marx and Freud, and which could be said equally of Nietzsche, asserts that "Things natural and social are not what they seem to be. What parades as truth in matters political is but a delusion of self and of others or a pretense, masking interests of class 
and the desires of self" $(1958,4,1962 b, 4)$. And yet he also resists the full implication of this critique when he adds: "This is no doubt so, sometimes or even often. But the whole history of the race and our own inner experience militates against the assumption that it is so always" $(1958,4,1962 \mathrm{~b}$, 4). The Nietzschean critique implies for Morgenthau that any restoration of timeless elements cannot and should not entail an uptake of that tradition wholesale. It entails a process necessarily involving "discarding, affirming, and refashioning", the results of which can only ever be "tentative and fragmentary" (1958, 3-4, 1962b, 3-4). Unpacking further the nature of the suffering, tragedy and guilt that Morgenthau associates with the shock of wonderment by way of an exploration of one trajectory that manifests it - that of the desire for justice, a key trajectory on Morgenthau's view-reveals the sources that Morgenthau thinks should be discarded, affirmed and refashioned. So doing also shows that his claim to a distinction between religion and religiosity belies the extent to which particular symbolic expressions of historic religion are operative within the purportedly common human experience of suffering as well as the very attitude of religiosity that he claims to be outwith and indeed without religion.

\section{The Trajectory of the Desire for Justice}

Morgenthau insists that "mankind has at all times refused to forgo ethical evaluation of political action. Political philosophy from the Greeks to our time has started with the assumption that man in the political sphere is not allowed to act as he pleases and that his action must conform to a standard higher than the standard of success" (1947, 151-152). "Man is a political animal by nature", he notes, while adding that, "he is a moralist because he is a man" $(1947,145)$. For Morgenthau, then, humanity is not merely a political animal that strives after power but also a moral animal that, in the face of the shock of wonderment, desires after justice and thus seeks to transcend itself in so doing.

\section{The Trajectory as Oriented}

Morgenthau's specific understanding of this trajectory of the desire for justice takes its shape in part from Aristotle. Anthony Lang $(2004,2007)$ has identified Morgenthau's emphasis on humanity as a moral animal and his emphasis on practical judgment as derivative of Aristotle, the latter claim noted also by Seán Molloy (2009). That Aristotle weighs upon 
Morgenthau's thought in these respects is certainly the case, but the manner in which Aristotle influences Morgenthau in these respects requires supplementation and amendment.

The supplementation required is attention to Morgenthau's uptake of Aristotle's mega thaumazein, the shock of wonderment. ${ }^{8}$ Morgenthau turns to the mega thaumazein in light of what he sees as the disillusionment with modern rationalization stemming from the fact that, while science and technology bring significant advancements, these advancements also entrap humanity and threaten the freedom they promise $(1972,2-4)$. It is also significant, Morgenthau notes, that in the face of the disillusionment with modern rationalization, two historically available answers to the question of the meaning of human rationality no longer seem to follow by necessity. Both the ancient understanding of the immanent value of science and the modern understanding of the transcendent value of science linked with moral and material progress seem to be merely one option among others rather than necessities beyond which there is no alternative. This is the case because each is couched within a broader way of life from which it derives its meaning, but the necessary link between that way of life and the understanding of the meaning of science has been broken. The ancient notion of the immanent value of science collapsed in the face of the modern experience of the transcendent justification of knowledge, and the modern notion of the transcendent value of science crumbled with the experience of carnage and destruction in the late-nineteenth and twentieth centuries. In short, Morgenthau implies, the late-modern moment is one marked by an experience of the perspectival character of human rationality and its meaning $(1972,5-10)$. With this recognition of the perspectival character of knowledge, Morgenthau traverses the sort of Nietzschean territory flagged by Ulrich Petersen $(1999,94)$ which indeed gives rise to a certain existential shock. But Morgenthau's turn to the mega thanmazein in the face of this late-modern experience would suggest a distinct reading of that crisis as well as a distinct response, one that, while embracing a certain epistemological skepticism akin to Nietzsche, holds also to a certain sense of objective meaning to existence.

It is the mega thaumazein, suggests Morgenthau, which provides an avenue by which to understand the meaning of human rationality when both the immanent meaning of human rationality of the ancients and the modern notion of its meaning as derivative of moral and material progress have become suspect. Morgenthau notes that, for Socrates, wonder is the beginning of philosophy. Aristotle picks up this sentiment but claims that 
the mega thaumazein is as an experience possible for more than merely the philosophers; while some pursue this wonderment through philosophy, others pursue it through religious myth. Morgenthau then extends this line of reasoning in suggesting that the mega thaumazein spurs various trajectories indicative of human existence-for union with the divine, love, power, knowledge, freedom and justice (1972, 24-25, 60; Voegelin 2000, 251). Given the Aristotelian provenance, this shock of wonderment is not the Nietzschean shock that Petersen $(1999,90)$ makes it out to be. For Morgenthau, consciousness cannot close the gap between itself and experience as it could in the Aristotelian notion of consciousness as the meeting ground of divine intellect and human intellect. In this respect, and in addition to the epistemological skepticism that he shares with Nietzsche, Morgenthau operates on a Nietzschean plane "under an empty from which the gods have departed" (1948, 196; see also 1962c, 14). But, this does not mean for Morgenthau that this wonderment is wholly without direction, for it is still oriented in the sense that the anxious desire instilled by the shock of wonderment is itself animated by a certain inchoate knowing to desire (Voegelin 2000, 249-250). The existential shock of anxious wonderment as characterized by Morgenthau is thus on a different register than for Nietzsche, for it rests within a larger order, however unknowable. That said, it would be a mistake to understand this inchoate knowledge within the parameters of Aristotelian teleology, for Morgenthau rather understands this orientation akin to the Kantian notion of a regulative idea $(2004,105-107,122-123)$. It is this regulative character of the shock of wonderment which represents the need not merely to supplement Lang's and Molloy's emphasis on the influence of Aristotle by foregrounding the central place of the mega thaumazein in Morgenthau's understanding of the trajectory of the desire for justice, but also the need to amend Lang's and Molloy's interpretation of Morgenthau by drawing attention to the manner in which Morgenthau's uptake of Aristotle is situated within a broader Kantian framework. ${ }^{9}$

\section{The Moral Dualism of the Trajectory}

The crucial distinction between Morgenthau and Aristotle is Morgenthau's notion of the desire for justice as an antinomy between the finite and infinite. Morgenthau's understanding of the pole of the infinite in the trajectory of the desire for justice-otherwise stated, that toward which this desire strives-is distinct from Aristotle's, and by implication, so is 
Morgenthau's understanding of the pole of the finite. Whereas Aristotelian ethics is concerned with the good for man in situation, the character of ethics in modernity, according to Morgenthau, is dualistic; it rests upon "a transcendent conception that is not inherent in the nature of man but is imposed upon man by supranational power" $(2004,92)$.

For Morgenthau, the infinite pole of the trajectory of the desire for justice is the moral law as absolute transcendent principle. In a manner striking given its uptake of symbolic expression of historic religion, Morgenthau traces the origin of the dualistic character of modern ethics to what he claims is the moral insight introduced by the Judeo-Christian tradition - the notion of ethics as law. On Morgenthau's view, the paradigmatic moment in the Judeo-Christian understanding of ethics "is Moses coming down from Sinai with the tablets of the law" $(2004,92)$. The law descends to humanity from elsewhere, on Morgenthau's reading, and imposes upon humanity a code to address its baseness; there is human finitude and the perverse character of human desire on the one hand and a transcendent code on the other. Morgenthau also reads this purportedly paradigmatic moment in the Judeo-Christian notion of ethics into what Weber $(1946,149)$ terms "Christian ethics". The extension of the commands "You shall love the Lord your God" and "You shall love your neighbour as yourself" in the command "Love your enemy as yourself"more broadly stated as the love commandment, ${ }^{10}$ and central to what both Weber and Morgenthau term "Christian ethics"-is, according to Morgenthau, of the same order as the Decalogue as he reads it. In short, Morgenthau understands both the Decalogue and the love commandment-that is, "Christian ethics" - akin to the Kantian notion of obligation and duty and juxtaposed to human desire and inclination understood as base. For Morgenthau, the commandment to love concerns the practical love of which Kant speaks when he speaks of the respect for persons as ends, a practical love that Kant separates from the pathological love of desire and inclination that is to be banished from the moral realm (Ricoeur $1995 \mathrm{~b}, 318,320)$. Hence, "the very core of Judeo-Christian morality", according to Morgenthau, is "respect for man as an end in himself" (1962g, 319).

It is the existence of the absolute, transcendent principle of the moral law-which represents the infinite pole toward which the trajectory of the desire for justice is oriented-that makes of humanity a moral animal and gives meaning to politics. It is humanity's orientation to, its pure desire for, the moral law, according to Morgenthau, that makes for the specifically 
human character of human being, setting it apart from the status of animal. Hence, Morgenthau asserts that "The moral law is not made for the convenience of man, rather it is an indispensable precondition for his civilized existence.... That is to say, human existence, not in its animal but in its civilized qualities, cannot find its meaning within itself but must receive it from a transcendent source" (1962a, 373). Morgenthau warns that by ignoring the moral law for individual convenience, the very possibility of civilized existence falls into jeopardy, even quoting Kant to assert that the disappearance of the moral law would lead to the loss of meaning of human existence (1962a, 373). He scolds the students of Columbia University, stating that "since your lives have lost the vital contact with the transcendence of the moral law, you find no reliable standard within yourself by which to judge and act. You are frightened by the emptiness within yourself, the insufficiency stemming from a self-contained existence" (1962a, 374). For Morgenthau, then, it is the desire for the moral law that gives to humanity the possibility of self-transcending, that is, the possibility of checking human desires and inclinations that Kant labels as impure, pathological desires and which for Morgenthau most potently manifest themselves in that other desire also indicative of human being, the infinite desire for power which is the animus dominandi.

While the moral law represents the infinite pole of the trajectory of the desire for justice, this trajectory also has a particular finite pole that makes of the trajectory an antinomy. The finite pole pertains to humanity's inability to attain to the moral law. For Morgenthau, this inability arises for a number of reasons, reasons which together represent two manifestations of the mega thaumazein that Morgenthau terms the intellectual and moral dilemmas of politics (1962d, 309, 1962f, 7-8, 1972, 10). A first reason pertains to the inability to fully know the moral law. While Morgenthau argues for the recognition of universal moral principles that transcend any particular historical instantiation, he argues equally against a position that would imply that one has direct access to such principles. On the one hand, he asserts that "[the moral code] is something objective that is to be discovered. It is not a product of history" $(1979,10)$. Yet, on the other hand, he acknowledges that any expression of the moral law is finite because it is necessarily bound to the specific historical instantiations through which it is articulated. Justice therefore cannot be fully known because knowledge of it is always perspectival; it is shaped by finite points of view as to what the world is like, what the world is for and the corresponding values associated with that view (1970, 63, 1974, 166-170). 
Hence, Morgenthau states: "I think justice or the good can be defined, but the definition is bound to be empty and abstract. And has to be filled with historic content. Here the problems and difficulties arise" (2004, 102). Any articulation of the demand of duty, Morgenthau recognizes, will necessarily be filtered through the contingent and limited understandings of a particular time and place. A second reason, and related to the first, stems from the fact that universal standards in their abstract form cannot simply be applied to action; rather, they must be filtered through the particularity of concrete political circumstances through an exercise of practical judgment. To assert the principle of "just due" or the principle "Thou shalt not kill", Morgenthau states, necessitates not only a concrete normative standard but also attention to the specifics of the situation at hand (1962e, 17-18, 1962h, 108, 1970, 63-64, 1974, 168, 2004, 94). These two reasons exhibit the intellectual dilemma of politics, for they pose the question of "what man is able to know in view of the capacity of his brains" $(1972,10)$, of the extent to which humanity can discern between the perennial and the ephemeral (1962f, 8).

Yet, the intellectual dilemma encompasses only some of the reasons as to why humanity fails to attain to the moral law. Others fall within the parameters of the moral dilemma, which raises the question of whether humanity could enact justice even if it were to be grasped, however inchoately. A third reason for humanity's inability to attain to the moral law pertains to the fact that consequences do not always align with intentions. This is the case, Morgenthau states, because humanity does not have the capacity to predict outcomes in a complex world; upon entering the world of action, an act mixes with a multitude of unpredictable and incalculable factors such that the possibility of unintended consequences always arises (1947, 162). Consequences do not always align with intentions also, and this represents a fourth reason, because there is a plurality of incompatible demands on good intentions which supersede the ability to satisfy them. The clash between moral duty to nation and the moral duty toward humanity is just one such example of how the satisfaction of one demand entails a violation of the other. Hence, the plurality of competing goods implies a corruption of pure intention even before action unfolds in the practical realm $(1947,162-163)$. A fifth reason, and related to the fourth, is that unintended consequences arise from the fact that unselfishness is itself premised on selfishness for its very possibility. Morgenthau states, “...the demands which poverty alone puts to our unselfishness are so overwhelming that any attempt at even faintly approximating unselfishness 
would of necessity lead to the sacrifice of the individual and would thus destroy his ability to contribute at least a certain share of unselfishness to the overwhelming demands of the world" $(1947,164)$. Or, as he also states: "After satisfying the demands of self, even if they were not inflated as they generally are, what is left over is not enough to go around" (1970, 66). Given the reality of scarcity, there exists a paradox at the heart of the logic of unselfish intention that lends legitimacy to selfishness and thus to conflict; the possibility of unselfishness rests upon selfish procurement of goods for sustenance and survival so as to make unselfishness possible. Thus, although the fifth reason introduces the demand of the self into the already competing mix of external demands, like the fourth reason, it reveals the "predicament of poverty". "However one may try", states Morgenthau, "the accounts of justice never square, because there is too much demanded and not enough to give" $(1970,66)$.

The above three reasons, which show how unintended consequences blemish pure intention, together reveal the finitude of human capacity. "We think we know what justice requires", states Morgenthau, "and we are resolved to act in accordance with it, but we do not have what it takes to do it. We know what we ought to do, and we want to do it, but we cannot" $(1970,65)$. Significantly, he then adds: "That is the tragedy of trying to be just" $(1970,65)$. Thus, the finitude of the incapacity to predict unintended consequences as well as to satisfy all of the demands upon the self leads to the failure to adequately treat others as ends. Moreover, it makes of human existence a tragedy and situates humanity as guilty. Here, the trajectory of the desire for justice exhibits a distinct shape to that of Aristotle's conception of justice, colored by the uptake of the symbol of the moral law read through a Kantian lens.

But the incapacity at the above three levels does not exhaust the moral dilemma of politics. The sixth reason, on Morgenthau's view, as to why humanity cannot attain to the moral law is no longer the incapacity of human reason to grasp the moral law given the finite character of human reason that inescapably operates within historical context. Nor is it an issue of unintended consequences, or of clashes between incommensurable values or of the relation of selfishness to unselfishness. Such are all instances of human finitude. This sixth reason is more fundamentally the issue of a perverse incapacity of the will, what Morgenthau calls the animus dominandi. It is the animus dominandi that prevents the attainment of the demand to treat others as ends by way of disinterested adherence to the moral law because the desire to dominate others as means is insatiable. 
The animus dominandi differs from selfishness in that selfishness has a limit, while the lust for power has no bounds. He states:

The desire for power ... concerns itself not with the individual's survival but with his position among his fellows once his survival has been secured. Consequently, the selfishness of man has limits; his will to power has none. For while man's vital needs are capable of satisfaction, his lust for power would be satisfied only if the last man became an object of his domination, there being nobody above or beside him, that is, if he became like God. $(1947,165)$.

Evil in the world does not simply arise from an inability to predict consequences, from an inability to satisfy competing ethical demands or from the paradoxical nature of unselfishness, all of which give rise to unintended consequences. Evil also arises from perverse intention, from the drive to attain a godlike position of control over humanity and nature through totalization and domination. Thus, for Morgenthau, "The ultimately decisive question is not what man is able to know in view of the capacity of his brains, but what he wants to know from among the knowledge technically accessible to him" (1972, 10). The animus dominandi brings to light “doubt about man's ability to grasp what meaning there is in history, given the involvement of his pride and aspirations in the historic process" (1962f, 8). The animus dominandi reveals, in the words of Reinhold Niebuhr (1996, 181), a "conscious perversity" at the heart of human freedom and action; this perversity is not mere ignorance of ignorance but the attempt to hide ignorance by overemphasizing the capacity for knowledge and to hide insecurity by extending the capacity for power beyond its limits. For Morgenthau, acknowledgment of the animus dominandi is akin to "the Augustinian recognition of both the inevitability and the evilness of the lust for power" $(1947,170),{ }^{11}$ as well as the Kantian notion of radical evil which is rooted deeply in the nature of the will and thus shatters the rationalist distinction between rationality and irrationality as the basis for ethics (1947, 170-171).

\section{The Slippage Toward Ontological Dualism in the Trajectory}

This characterization of the animus dominandi implies that Petersen is mistaken in his assertion that one should interpret Morgenthau's notion of the animus dominandi in a Nietzschean light. Petersen $(1999,105)$ 
insists that Morgenthau's notion of the animus dominandi should be understood not as a metaphysical positing of a human nature along the lines of Augustinian original sin. Rather, he suggests, it represents an outgrowth of the ontological structure of human action as implied by a Nietzschean framework. He states:

The quality of action is thus not a direct product of human nature, apart from its mortality. Quite to the contrary, it seems to be the case that Morgenthau's notion of human nature is a product of the quality of action, which, in turn, derives from the ontological conclusions drawn from his Nietzschean metaphysics. That is to say, the animus dominandi is not about what man is as such but what he necessarily becomes when he takes a stand in the flow of becoming, when she makes manifest her wish for autonomy. It is a definition of social, not abstract, man. $(1999,104)$

In a similar vein, he emphatically asserts, "it is obvious that [Morgenthau's] definition of human beings follows not from an inherent psychological drive to do evil but from the fact that humans are social and acting beings" $(1999,106)$. According to Petersen, Morgenthau's notion of the animus dominandi "derives from his unflinching willingness to think through the political consequences of Nietzsche's reconfiguration of the relationship between man and his orders" $(1999,107)$. The animus dominandi is merely the reflection of humanity as will to power, as the necessary outcome of its effort to become; it is not, he asserts, a statement regarding what humanity fundamentally is.

Significant about this rendering is that it reduces the animus dominandi to the realm of finitude rather than seeing the animus dominandi as characteristic of humanity's "conscious perversity", which maintains the animus dominandi in the realm of human freedom and thus as a mixture of finitude and infinitude. ${ }^{12}$ But to reduce the animus dominandi in this manner is to conflate it with the other three above-mentioned reasonsthe inability to predict consequences as well as the "predicament of poverty" manifest both in the inability to satisfy competing external ethical demands and the inability to satisfy the ethical demands of the self and the other-as to why Morgenthau asserts that humanity is incapable of attaining to the moral law, all of which pertain to the issue of unintended consequences that surpass the desire of pure intention and thus render humanity guilty before the law. The animus dominandi pertains to the realm of intention, indeed to the very "conscious perversity" which 
manifests itself at the root of intention. While Morgenthau's discussion of totalization as part of the structure of action may perhaps align with Petersen's characterization of the Nietzschean understanding of the inevitable character of human becoming, Morgenthau is making a much more radical claim about the animus dominandi. Indeed, humanity cannot count on pure intention because of the integral connection between the desire to be and the structure of human action which falls short of the moral law by reducing persons to means; in this sense Morgenthau aligns with Petersen's Nietzschean reading. But, more radically yet, humanity cannot count on pure intention because of an insatiable lust for power, the animus dominandi, which injects itself within intention and perverts it. Prior even to action in the world, before even the moment of insertion into the flow of becoming, is the corruption of human intention by the insatiable drive for power over others out of the desire to attain godlike stature. Petersen is correct to emphasize that Morgenthau's uptake of Kant - which represents a contrast to "the most debilitating consequences of Nietzsche's thought" (1999, 107)—entails attention to consequences over mere intentions, and that in so doing Morgenthau reduces finitude to fault in a manner that transforms humanity's ethical condition into a vicious antinomy. But what Petersen misses is also the uptake of Augustine on original sin and of Kant on radical evil. The animus dominandi pertains not merely to the realm of finitude, it pertains also to the realm of human freedom and thus is a manifestation of humanity as a mixture of finitude and infinitude. As the philosopher Paul Ricoeur states, when interpreting Kant on radical evil, "evil is the origin of what we could call a pathology of totality, that is, the perversion of that impulse toward completeness" (1995a, 91). Hence, the animus dominandi turns the necessary structure of action - that of totalization, of a reduction of the whole to a part-into a pathology of totality. The ubiquity of the animusdominandi, Morgenthau states, "is the element of corruption and of sin which injects even into the best of intentions at least a drop of evil and thus spoils it. On a grand scale, the transformation of churches into political organizations, of revolutions into dictatorships, of love for country into imperialism, are cases in point" $(1947,167)$. The animus dominandi is a perversion of the will that reaches its extreme in those claims to totality so often most overtly manifest in church and state (Ricoeur 1995a, 76-77).

Petersen's reduction of the animus dominandi to finitude is premised on his problematic claim that Morgenthau adopts Nietzsche's notion of the will to power rather than a traditional notion of the will. And Petersen 
makes this claim because, in turn, he suggests that Morgenthau, like Nietzsche, holds an ontology that is "thoroughly antagonistic" (1999, 100). Hence, on Petersen's view, in the eyes of Morgenthau, "whatever unity there is must have been created; what is must have been made to fit through an act of power and violence" (1999, 99; emphasis in original). But, this is to mistakenly equate the "existential dread and suffering" of which Morgenthau speaks with a wholly Nietzschean rendition of the disenchantment of the modern world. As noted above, the suffering and anxiety of which Morgenthau speaks are better interpreted by way of Aristotle and Kant as a shock of wonderment which is oriented, and oriented specifically by the moral law.

When Petersen equates the animus dominandi with the Nietzschean will to power, it would seem that he is rather picking up on what Vassilios Paipais $(2013,855,2016,1612-1616)$ identifies as a certain Gnostic slippage in Morgenthau's thought. ${ }^{13}$ In asserting that the animus dominandi "is not a psychological principle simply to be equated with human inclinations" but rather "a principle that transcends and thus dismantles the modern concept of self, and as such it takes us beyond motives or desires" $(1999,99)$, Petersen draws attention to a passage in which Morgenthau notes that reason and consciousness are inextricably linked with the passions. Morgenthau states: "Those interests and emotional preferences are perhaps not a priori in the same sense in which philosophers like to think of the categories of our reasoning as a priori. But they are a priori with respect to the processes of reason which we apply to the social sphere" (1947, 134). But, it is crucial not to understand this priority to the passions in the sense of a Nietzschean perspectivism tied to a thoroughgoing antagonistic ontology. This is the case because even with the recognition of the priority of the passions, Morgenthau operates within a framework of good and evil delineated by the moral law, not a framework beyond good and evil. Morgenthau describes the animus dominandi with the language of corruption and guilt, even of $\sin (1947,167)$, that hardly accords with a Nietzschean sensibility. Morgenthau explicitly articulates his difference from Nietzsche in this respect when he suggests that a moral dualism-to which Morgenthau himself holds, and, again, is striking for its uptake of symbolic expression of historic religion-characterizes the modern sensibility, a sensibility against which Nietzsche railed in his criticisms of Christianity. Morgenthau states: 
you have in ancient Greece a situational ethics to begin with. You haven't got a transcendental ethics at all. So man can live in peace with himself on moral grounds much more easily as a Greek than as a member of the JudeoChristian society. And this, of course, is as I said last time, the main argument of Nietzsche against Christianity. That it tries to force man into a moral straightjacket that is against his nature.... Which leads to deception, to immoralities that were completely alien to the Greeks. The point I want to make again is that there exists a fundamental distinction between our conception of morality and the Greek conception and even other nonJudeo-Christian conceptions of morality. $(2004,95)$

Morgenthau seeks to highlight the stark divide between the Greek understanding, a Judeo-Christian notion of a transcendent morality taken up within modernity, and the Nietzschean attempt to recover a dimension of Greek moral innocence. To speak of the animus dominandi with the language of corruption, guilt and even sin is to hold to a conception that is at odds with a Nietzschean depiction that would seek to reject such language wholesale.

Instead of a Nietzschean will to power, what Petersen is rather bringing into relief is the Gnostic slippage in Morgenthau's thought according to which, as Paipais $(2016,1614)$ notes, his moral dualism slides into an ontological dualism. A Gnostic ontological dualism, as Morgenthau states,

is aware of the existence of two forces-God and the devil, life and death, light and darkness, good and evil, reason and passion-which struggle for dominance of the world. There is no progress towards the good, noticeable from year to year, but undecided conflict which sees today good, tomorrow evil, prevail; and only at the end of time, immeasurably removed from the here and now of our earthly life, the ultimate triumph of the forces of goodness and light will be assured. (1947, 175).

Gnostic dualism speaks of a good, transcendent deity starkly juxtaposed with a world which is the creation of a lesser, evil deity, as well as of a dichotomy between a base human body and an inner divine light entrapped within it which is the source of saving knowledge. This sharp differentiation is inexorable in the here and now, as Morgenthau notes, with the victory of good over evil immeasurably displaced from the present context. Such a Gnostic sensibility manifests itself in Morgenthau's thought at certain moments. In emphasizing that the unpredictability of human action and the "predicament of poverty" render corrupt even the best 
intentions and render them evil, Morgenthau insinuates a staunch distinction between a base, intransigent world and the good, moral law mirrored as an inner light in the form of an entrapped, pure intention. It also manifests itself, moreover, in those moments when Morgenthau renders the animus dominandi itself as preceding any meaningful realm of freedom. Such is evident in Morgenthau's characterization of a human "propensity for self-deception", which he contrasts with rational knowledge understood as the human capacity for self-transcendence and without which "the propensity for self-deception has free rein" $(1970,65) .{ }^{14}$ That such a characterization is Gnostic in temperament receives further confirmation when Morgenthau proceeds to state that:

It is the saving grace of ignorance and egotism that they are easily concealed. For if they were not, they would be a deadly affront to our need to be just. Thus, with that biological wisdom that is a quality not only of our bodies but of our minds as well, the poison of ignorance and egotism creates illusion as its own antidote. In order to save ourselves, we are not only able, but compelled, to delude ourselves into believing that ignorance is knowledge, and egotism impartiality. $(1970,65)$

In speaking of a "biological wisdom" that taints both body and mind, Morgenthau renders not only the finite but also the infinite side of human being to the side of an evil world; here, even the inner light of knowledge seems to necessarily, and not just inevitably, share in the corruption of a base body. Such assertions bring to light the Gnostic sensibility also manifest in Morgenthau's Pascalian assertion when understood to apply specifically to the trajectory of the desire for justice as an antinomy between the infinitude of the desire for the moral law and the finitude of the animus dominandi: "Suspended between his spiritual destiny which he cannot fulfil and his animal nature in which he cannot remain, he is forever condemned to experience the contrast between the longings of his mind and his actual condition as his personal, eminently human tragedy" (1947, 188). Or, in Morgenthau's assertion in slightly different terms that: "Man alone is, as it were, suspended between heaven and earth: an ambitious beast and a frustrated god. For he alone is endowed with the faculty of rational imagination that outpaces his ability to achieve" (1970, 61). Humanity, on this rendering, represents not a mixture of finite and infinite which would maintain the animus dominandi within the realm of human freedom but rather that which is torn between two poles in the sense of an 
infinite inner light oriented toward the moral law which is yet at the mercy of a finite (but infinite in its aspirations), perverse lust for power inherent to its embodied nature. ${ }^{15}$

Morgenthau's priority to the passions combined with a Gnostic notion of the passions as inherently evil in their quest for dominance, and, crucially, mixed with a Nietzschean sentiment of "an empty sky from which the gods have departed" can easily appear to resemble the Nietzschean will to power. Unlike Gnosticism, after all, Morgenthau does not hold to the notion of the triumph of the good principle, however immeasurably deferred; he rejects the notion of redemption whether understood with respect to a deity, or, one might add, if understood even with respect to the Kantian postulates of God and immortality (1948, 196, 1962c, 14). Yet, the rejection of the prospect of redemption notwithstanding, Morgenthau still operates with a notion of order framed as good and evil by the moral law, eliciting a certain desire and thus entailing also what Petersen characterizes as a traditional notion of the will. ${ }^{16}$ That Morgenthau's notion of the will is something that humanity has and must exercise within a realm of moral responsibility, rather than, as Petersen $(1999,95)$ claims, something that humanity simply is, is evident in the degree to which Morgenthau's moral dualism does not slide into an ontological dualism. Most notably, this is evident at those moments when Morgenthau frames his ethics of the lesser evil in the positive. Accordingly, the space of freedom that Morgenthau guards within his ethics of the lesser evil is a space wherein, Morgenthau implies, there can be the conscious exercise of political wisdom, moral courage, and moral judgment as a means by which to reconcile "[humanity's] political nature with [its] moral destiny" (1947, 173).

Yet, the antinomy at the heart of Morgenthau's ethics of the lesser evil remains inexorable, running the risk of undercutting the very resources that might sustain it because of the slippage from a moral dualism to a Gnostic ontological dualism. ${ }^{17}$ Hence, Morgenthau more often than not frames it instead in the negative. The only possibility is to attempt to minimize the extent to which action diverges from the moral law. States Morgenthau: "While he is precluded from acting morally, the best he can do is to minimize the intrinsic immorality of the political act. He must choose from among the political actions at his disposal the one which is likely to do the least violence to the commands of Christian ethics. The moral strategy of politics is, then, to try to choose the lesser evil" (1962e, 16). Because there is no possibility of harmonization between human 
action and the demand of the moral law, "The best man is capable of is to be guided by the vision of a life lived in compliance with the Christian code and to narrow the gap between his conduct and that code" (1962e, 15). Theology, he notes, speaks of such a harmonization through divine grace; but, for Morgenthau, no such notion of divine grace is operative (1948, 196, 1962c, 14). Hence, as Morgenthau states in the negative, humanity can hope only to be not too evil (1947, 165). Any selftranscending along the trajectory of the desire for justice is, for Morgenthau, that of a finite realization in the negative; it is nothing more than the minimization of the worst conflagrations. In this respect, Petersen $(1999,107)$ is correct that Morgenthau's outlook is aptly characterized as a "Kantianism without redemption".

The Gnostic slippage from a moral dualism to an ontological dualism reveals a final characterization of the tragedy and guilt that Morgenthau understands to be characteristic of the shock of wonderment. That this experience is one of tragedy and guilt is because there exists an order delineated by the moral law, but an order in which humanity's baseness pertains not merely to its finitude in the sense of its inability to predict the consequences of action or to overcome the "predicament of poverty", nor even to its "conscious perversity" according to which it pursues the "pathology of totality", but most fundamentally to its very animal nature which taints even humanity's inner light. Yet, this final characterization is indeed a slippage, for it rests uneasily with Morgenthau's continual emphasis on the need for moral responsibility. Regardless of the wavering between moral and ontological dualism, the trajectory of the desire for justice and the broader shock of wonderment of which it is one manifestation is plagued by suffering in the form of tragedy and guilt because of the ursymbol on which it rests - that of "Moses coming down from Sinai with the tablets of the law" $(2004,92)$-and the particular reading of that symbol which affirms and refashions it according to a Kantian ethics of duty tinged with influences of Aristotle, Augustine, Gnosticism and Nietzsche. Morgenthau's religiosity - which he understands as the experience of suffering, tragedy and guilt transformed into conscious awareness such that humanity turns to transcendent guidance so as to reconcile itself with its own nature, its fellow human beings, and with the order of the universe $(1983,6)$ - is fundamentally infused with a symbolic expression of historic religion to a degree that he does not seem to acknowledge when he distinguishes between religiosity and religion. Morgenthau's very religiosity, as well as his very claim to a lived experience purportedly 
fundamental to humanity writ large when he speaks of that religiosity, is already inflected through symbolic expression belonging to traditions of historic religion.

\section{Revisiting the Religion and Religiosity Distinction}

It is important to reiterate that Morgenthau's reading of the ur-symbol in his thought, that of Moses descending Mount Sinai with the law, is indeed a particular reading. Indeed, a contrast with the reading of the Mosaic Law and of the love commandment central to "Christian ethics" undertaken by Ricoeur reveals the very particularity of Morgenthau's uptake of these symbolic expressions. As Ricoeur (1995b) notes, in drawing from the German Jewish philosopher Franz Rosenzweig, the commandment to love and the Decalogue of which it is an extension can be read in a manner other than the form of a command ethics that compels human freedom through obligation. The love commandment and the Decalogue can themselves be read as extensions of a more primary movement. ${ }^{18}$ This movement is that of the plea of the lover to the beloved expressed in the poetic language of the Song of Songs: "Love me!". This movement, notes Ricoeur, is a form of commandment which is not law, which does not take on the form of obligation. It compels through the very manner by which it offers itself-as a plea and an extension of desire for union. Understood as the ur-moment, this plea situates the Mosaic Law and the love commandment within a much longer history and thus as an outgrowth of a more fundamental movement of the extension of and call for love. What the location of this ur-moment of the plea "Love me!" also implies is a beloved that is capable, however incompletely, of response to the plea in turn, rather than a will so perverted that it faces off against an impossible command. In short, it implies a finitude that is not yet fault, that is not yet marred by guilt. And this is a symbolic expression with implications significantly different from the symbolic expressions of law and perverted will upon which Morgenthau draws, for it both suggests an altogether different characterization of the experience in the face of the unforeseen and unintelligible - one not ultimately marred by tragedy and by guilt-and it provides images that might serve as the basis and inspiration for transformed action in the political realm.

The implication of Morgenthau's particular uptake of symbolic expressions of historic religion and the resulting inability to speak of a finitude that it not yet fault is that Morgenthau's very desire to hold to the 
possibility of achieving, if not the good, at least a position that is not too evil seems to risk the inability to garner the resources by which to sustain the realization of such a possibility. Morgenthau does speak of the finite pole of the trajectory of the desire for justice in the terms of an approximation to the moral law. For Morgenthau, justice is nameable, however incompletely. Furthermore, Morgenthau does speak of the animus dominandi as a drop of evil that spoils what are otherwise the best of intentions. Yet, he provides little indication as to how the goodness of the intention that is spoiled might be discerned, a goodness that might orient the lesser evil. In short, Morgenthau's limited reflections upon, or indeed outright dismissal of, a desire that is not pathological and a finite approximation that is not yet fault renders his understanding of the trajectory of the desire for justice a vicious antinomy. Attention to a lesser evil and the pathological character of human desire about which it sheds light overwhelms attention to an efficacy of justice in the world, to premonitions or anticipations from which to build. Attention to gradations of evil to which the lust for power points overwhelms attention to gradations of good. The ethical stakes of the trajectory of the desire for justice clash incessantly with little to no mediation; there is, on the one hand, the unachievable moral law that arrives in the form of the imperative, and, on the other hand, finite realizations marked by their character of guilt rather than by imperfect and incomplete goodness.

\section{Notes}

1. Thanks to Vassilios Paipais for helpful discussions and comments related to themes in this chapter.

2. Morgenthau (1972, 65-66, 1983, 6) elsewhere draws a distinction between "religion" and a "religious attitude" or "religious impulse" with much the same meaning intended.

3. For an informative article on Morgenthau's religiosity, see M. Ben Mollov (1998).

4. For a foregrounding of the problematic of the relation between the claim to immediacy indicative of lived experience and the reality of cultural and historical mediation from which this argument draws inspiration, see Paul Ricoeur (2000, 129-132).

5. Affinities with Kierkegaard's (1980) notion of anxiety are apparent here and help to elucidate the common ground between Morgenthau and Reinhold Niebuhr. For a discussion of the relationship between Morgenthau 
and Niebuhr see Daniel Rice (2008) and for a discussion of anxiety with respect to Niebuhr, see Caron Gentry (2019).

6. It would seem that, for Morgenthau, the institutional, propositional and ritualistic dimensions of religion tend toward the form of irreligiosity.

7. Ulrich Petersen $(1999,90)$, while quoting Morgenthau on the effect of the Nietzschean critique, does not acknowledge that succeeding statements reveal his evident departure from the supposition that this effect need be the case.

8. Morgenthau $(1984,4)$ notes that Aristotle's mega thaumazein shaped his thinking already as a first-year undergraduate student.

9. Molloy $(2009,101)$ seems to acknowledge as much, although the thrust of his argument places the attention on Aristotle rather than Kant.

10. For a discussion of the love commandment, see Paul Ricoeur (1995b).

11. That Morgenthau is here moving within the horizon of Augustine's reflections on original sin is further evident in his explicit reference to "St. Augustine's animus dominandi" (1972, 31). Alastair Murray (1996, 1997) has made much of this Augustinian influence. For a discussion of original sin, see Ricoeur (2007), as well as Paipais (2019) for a direct link with international politics.

12. It is important to here remember that the lust for power itself represents a distinct trajectory with a finite and infinite pole. It is the incursion of the animus dominandi into the trajectory of the desire for justice that, for Morgenthau, contributes in part to the trajectory's antinomic character.

13. It is a slippage in that it runs contrary to Morgenthau's own continual call for moral responsibility in the political realm.

14. Rational should here not be understood in the sense of rationalist, which is so often the target of Morgenthau's disdain. Rational knowledge in this sense implies rather an awareness of limits-as, for example, expressed in Morgenthau's (1947, 176) reference to Goethe-from which only can arise the possibility for humanity to transcend itself toward an approximation of justice. The echoes here of the Gnostic notion of saving knowledge as that which pertains to knowledge of the origins of the evil world and which gives rise to self-transcendence should not go unnoticed.

15. Morgenthau here rehearses Augustine's quasi-Gnostic slippage, albeit to a greater degree. Indeed, it is this degree of Gnostic slippage which causes Roger Epp (1991, 25n70) to remark that it is surprising "that [Morgenthau's] ideas should have borrowed at all from an Augustinian theological idiom".

16. Hans Jonas (1952) provides an informative discussion of similarities and differences between Pascal, existentialism, Gnosticism and Nietzschean nihilism. 
17. Paipais (2016, 1614-1615) suggests that the danger is that Morgenthau's ethics of the lesser evil runs the risk of collapsing into "anthropological pessimism or heroic fatalism”.

18. Morgenthau $(1974,168)$ seems to recognize as much in at least one instance.

\section{REFERENCES}

Blumenberg, H. (1983). The Legitimacy of the Modern Age (R. M. Wallace, Trans.). Cambridge, MA: MIT Press.

Epp, R. (1991). The "Augustinian Moment" in International Politics: Niebuhr, Butterfield, Wight and the Reclaiming of a Tradition. International Politics Research Paper Number 10. Aberystwyth, UK: Department of International Politics University College of Wales, Aberystwyth.

Frei, C. (2001). Hans J. Morgenthau: An Intellectual Biography. Baton Rouge, LA: Louisiana State University Press.

Gauchet, M. (1997). The Disenchantment of the World: A Political History of Religion (O. Burge, Trans.). Princeton, NJ: Princeton University Press.

Gentry, C. E. (2019). Anxiety Politics: Creativity and Feminist Christian Realism. Journal of International Relations and Development, 22(2), 389-412.

Jonas, H. (1952). Gnosticism and Modern Nihilism. Social Research, $19(1), 430-452$.

Kierkegaard, S. (1980). The Concept of Anxiety: A Simple Psychologically Orienting Deliberation on the Dogmatic Issue of Hereditary Sin (R. Thomte, Ed. \& Trans.). Princeton, NJ: Princeton University Press.

Lang, A. F., Jr. (2004). Introduction to Political Theory and International Affairs: Hans J. Morgenthau on Aristotle's The Politics (Morgenthau, H. J.) (A. F. Lang, Jr., Ed.) (pp. 1-14). Westport, CT: Praeger Publishers.

Lang, A. F., Jr. (2007). Morgenthau, Agency, and Aristotle. In M. C. Williams (Ed.), Realism Reconsidered: The Legacy of Hans Morgenthau in International Relations (pp. 18-41). Oxford: Oxford University Press.

Lefort, C. (1988). The Permanence of the Theologico-political? In Democracy and Political Theory (D. Macey, Trans.). Cambridge: Polity Press.

Löwith, K. (1949). Meaning in History. Chicago: University of Chicago Press.

Mollov, M. B. (1998). Power and Spirituality in the Thought of Hans J. Morgenthau. Jewish Political Studies Review, 10(1-2), 93-112.

Molloy, S. (2009). Aristotle, Epicurus, Morgenthau and the Political Ethics of the Lesser Evil. Journal of International Political Theory, 5(1), 94-112.

Morgenthau, H. J. (1947). Scientific Man vs. Power Politics. London: Latimer House.

Morgenthau, H. J. (1948). Politics Among Nations: The Struggle for Power and Peace. New York: Alfred A. Knopf. 
Morgenthau, H. J. (1958). Introduction: Dilemmas of Politics. In Dilemmas of Politics. Chicago, IL: University of Chicago Press.

Morgenthau, H. J. (1962a). Epistle to the Columbians on the Meaning of Morality. In Politics in the Twentieth Century (Vol. 1), The Decline of Democratic Politics. Chicago: University of Chicago Press.

Morgenthau, H. J. (1962b). Introduction. In Politics in the Twentieth Century (Vol. 1), The Decline of Democratic Politics. Chicago: University of Chicago Press.

Morgenthau, H. J. (1962c). Love and Power. In Politics in the Twentieth Century (Vol. 3), The Restoration of American Politics. Chicago: University of Chicago Press.

Morgenthau, H. J. (1962d). The Autonomy of Political Action. In Politics in the Twentieth Century (Vol. 1), The Decline of Democratic Politics. Chicago: University of Chicago Press.

Morgenthau, H. J. (1962e). The Demands of Prudence. In Politics in the Twentieth Century (Vol. 3), The Restoration of American Politics. Chicago: University of Chicago Press.

Morgenthau, H. J. (1962f). The Intellectual and Moral Dilemma of Politics. In Politics in the Twentieth Century (Vol. 1), The Decline of Democratic Politics. Chicago: University of Chicago Press.

Morgenthau, H. J. (1962g). The Moral Dilemma of Political Action. In Politics in the Twentieth Century (Vol. 1), The Decline of Democratic Politics. Chicago: University of Chicago Press.

Morgenthau, H. J. (1962h). The Problem of the National Interest. In Politics in the Twentieth Century (Vol. 1), The Decline of Democratic Politics. Chicago: University of Chicago Press.

Morgenthau, H. J. (1962i). The Rediscovery of Imagination and Religion: Arnold Toynbee. In Politics in the Twentieth Century (Vol. 3), The Restoration of American Politics. Chicago: University of Chicago Press.

Morgenthau, H. J. (1970). On Trying to Be Just. In Truth and Power: Essays of a Decade, 1960-70. London: Pall Mall Press.

Morgenthau, H. J. (1972). Science: Servant or Master? New York: New American Library.

Morgenthau, H. J. (1974). Justice and Power. Social Research, 41(1), 163-175.

Morgenthau, H. J. (1979). Human Rights and Foreign Policy. CRIA Lecture on Morality and Foreign Policy. New York: Council on Religion and International Affairs.

Morgenthau, H. J. (1983). The Mind of Abraham Lincoln: A Study in Detachment and Practicality. In Essays on Lincoln's Faith and Politics (Morgenthau, H. J., \& Hein, D.) (K. W. Thompson, Ed.) (pp. 3-101). Lanham, MD: University Press of America.

Morgenthau, H. J. (1984). Fragment of an Intellectual Autobiography: 1904-1932. In K. Thompson \& R. J. Myers (Eds.), Truth and Tragedy: A 
Tribute to Hans J. Morgenthan (pp. 1-17). New Brunswick, NJ: Transaction Books.

Morgenthau, H. J. (2004). Political Theory and International Affairs: Hans J. Morgenthau on Aristotle's The Politics (A. F. Lang, Jr., Ed.). Westport, CT: Praeger Publishers.

Murray, A. J. H. (1996). The Moral Politics of Hans Morgenthau. The Review of Politics, 58(1), 81-107.

Murray, A. J. H. (1997). Reconstructing Realism: Between Power Politics and Cosmopolitan Ethics. Edinburgh: Keele University Press.

Niebuhr, R. (1996). The Nature and Destiny of Man: A Christian Interpretation (Vol. 1), Human Nature. Louisville, KY: Westminster John Knox Press.

Oakeshott, M. (1993). Scientific Politics. In Religion, Politics, and the Moral Life (T. Fuller, Ed.). New Haven, CT: Yale University Press.

Paipais, V. (2013). Necessary Fiction: Realism's Tragic Theology. International Politics, 50(6), 846-862.

Paipais, V. (2014). Between Politics and the Political: Reading Hans J. Morgenthau's Double Critique of Depoliticisation. Millennium: Journal of International Studies, 42(2), 354-375.

Paipais, V. (2016). Overcoming 'Gnosticism'? Realism as Political Theology. Cambridge Review of International Affairs, 29(4), 1603-1623.

Paipais, V. (2019). First Image Revisited: Human Nature, Original Sin and International Relations. Journal of International Relations and Development, $22(2), 364-388$.

Petersen, U. E. (1999). Breathing Nietzsche's Air: New Reflections on Morgenthau's Concepts of Power and Human Nature. Alternatives: Global, Local, Political, 24(1), 83-118.

Rengger, N. J. (2000). International Relations, Political Theory and the Problem of Order: Beyond International Relations Theory? London: Routledge.

Rengger, N. J. (2007). Realism, Tragedy, and the Anti-Pelagian Imagination in International Political Thought. In M. C. Williams (Ed.), Realism Reconsidered: The Legacy of Hans Morgenthan in International Relations (pp. 118-136). Oxford: Oxford University Press.

Rice, D. (2008). Reinhold Niebuhr and Hans Morgenthau: A Friendship with Contrasting Shades of Realism. Journal of American Studies, 42(2), 255-291.

Ricoeur, P. (1995a). A Philosophical Hermeneutics of Religion: Kant. In Figuring the Sacred: Religion, Narrative, and Imagination (M. I. Wallace, Ed., \& D. Pellauer, Trans.). Minneapolis, MN: Fortress Press.

Ricoeur, P. (1995b). Love and Justice. In Figuring the Sacred: Religion, Narrative, and Imagination (M. I. Wallace, Ed., \& D. Pellauer, Trans.). Minneapolis, MN: Fortress Press.

Ricoeur, P. (2000). Experience and Language in Religious Discourse (J. L. Kosky, Trans.). In Phenomenology and the 'Theological Turn': The French 
Debate (Janicaud, D., Courtine, J.-F., Chrétien J.-L., Henry, M., Marion, J.-L., \& Ricoeur, P.) (pp. 127-146). New York: Fordham University Press.

Ricoeur, P. (2007). 'Original Sin': A Study in Meaning (P. McCormick, Trans.). In The Conflict of Interpretations: Essays in Hermeneutics (D. Ihde, Ed.). Evanston, IL: Northwestern University Press.

Scheuerman, W. E. (2009). Hans Morgenthau: Realism and Beyond. Cambridge: Polity Press.

Schmitt, C. (2005). Political Theology: Four Chapters on the Concept of Sovereignty (G. Schwab, Trans.). Chicago: University of Chicago Press.

Taylor, C. (2007). A Secular Age. Cambridge, MA: Belknap Press of Harvard University Press.

Voegelin, E. (2000). Order and History (Vol. 4), The Ecumenic Age (M. Franz, Ed.). Columbia, MO: University of Missouri Press.

Weber, M. (1946). Science as a Vocation. In From Max Weber: Essays in Sociology (H. H. Gerth \& C. W. Mills, Trans. \& Ed.). New York: Oxford University Press. 